\title{
Effect of Corporate Social Responsibility Reporting on Profitability of Selected Manufacturing Firms in Nigeria
}

\author{
Adedeji Elijah Adeyinka Odeh Emmanuel Ikande \\ The Federal University of Technology, Akure, Ondo State
}

\section{ABSTRACT}

The performance of business organizations in the present knowledge based and an increasing more competitive economy is affected by their strategies and operations in market and nonmarket environments. Hence, there is a debate on the extent to which company directors and managers should consider social and environmental factors in making decisions. It is therefore against the foregoing that this study examined the impact of corporate social responsibility reporting on profitability of selected manufacturing firms in Nigerian for the period 2013 to 2017.

The study was a descriptive research of survey type. The population of the study comprises fifty-three in number out of which six companies were purposively selected as sample. The selected companies have their corporate headquarters in Lagos. This study uses data mainly from secondary sources made up of the financial statement for each year covered by the study. The study covered a period of five years from 2013-2017. The analysis were done using descriptive statistics such as mean, standard deviation, kurtosis and skeweness as well as inferential statistics such as panel regression and pearson product moment correlation.

The result of the correlation matrix for the relationship between the two variables ranges between $2 \%$ and $40 \%$. The result of the panel regression used in relating the joint power of the variables showed p-value of 0.0000 which made the model to be fitted at $1 \%$ level of significant. The study however found that the impact of corporate social responsibility has positive and significant impact on net profit of manufacturing firms in Nigeria. The implication is that, as the companies add to the social wellbeing of the society where the company is located it affects their return in terms of profit positively. This result reinforces the accumulating body of empirical support for the positive impact of CSR on firm's profitability.

From the findings, the researcher therefore conclude that companies that place more emphasis on CSR, measuring it and treating it an obligation will stand apart. Also, companies that do a proper job of making sure that the society to which they belong, feels their impact are going to be in a position to have a sustainable competitive advantage. Companies should therefore ensure they act as good citizen of the society to which they belong for the ongoing success of the business. The study recommended that manufacturing companies should increase their dedication to giving back to the society, by formulating a framework for CSR spending to boost the standard of live of Nigerians to the point that their social reputation will engender positive and substantial increase in their profitability, as this is essential for their going concern in the country.

Keywords: Profitability, Corporate Social Responsibility, Companies, Environmental factors, Competitive Economy.

DOI: $10.7176 / \mathrm{RJFA} / 11-14-17$

Publication date:July $31^{\text {st }} 2020$

\section{INTRODUCTION}

The performance of business organizations is affected by their strategies and operations in market and nonmarket environments. Hence, there is a debate on the extent to which company directors and managers should consider social and environmental factors in making decisions. In essence, Corporate Social Responsibility (CSR) may be described as an approach to decision making which encompasses both social and environmental factors. It can therefore be inferred that CSR is a deliberate inclusion of public interest into corporate decision making, and the honoring of a triple bottom line which are People, Planet and Profit (Harpreet, 2009). CSR has been defined in various ways. Majority of these definitions integrate the three dimensions: economic, environmental and social aspects into the definition, what is usually called the triple bottom line. The triple bottom line is considering that companies do not only have one objective; profitability, but that they also have objectives of adding environmental and social value to society (Mirfazli, 2008). In recent years, customers, employees, suppliers, community groups, governments, and some share-holders have encouraged firms to undertake additional investments in corporate social responsibility (CSR). Some firms have responded to these concerns by devoting more resources to CSR. Other companies' managers have resisted, arguing that additional investment in CSR is inconsistent with their efforts to maximize profits. The resulting controversy has induced researchers to examine the relationship between CSR and financial performance, in an effort to assess the validity of concerns regarding a tradeoff between investment in CSR and profitability. 
CSR has been defined as a concept whereby companies integrate social and environmental concerns in their business operations and in their interaction with their stakeholders on a voluntary basis (Green Paper Promoting a European Framework for Corporate Social Responsibility (2001). Helg (2007) also defines CSR as the set of standards to which a company subscribes in order to make its impact on society. CSR can be defined as "a business organization's configuration of principles of social responsibility, processes of social responsiveness, and policies, programs, and observable outcomes as they relate to the company's societal relationships" (Wood 1991). CSR is more than just following the law (McWilliams \& Siegel, 2001). It is actions that companies take that goes beyond legal obligations. For CSR to be effective companies need to tie CSR principles with their objectives and it is important for the workers of the company to be committed to these principles.

The corporate social responsibility report issued by Nigerian enterprises started late, but under the influence of various policies and regulations, the research on social responsibility has developed rapidly. The number of companies that publish social responsibility reports in Nigeria has increased year by year (onyeka, 2016). In 2008, the Nigerian Stock Exchange had required listed companies to disclose relevant social responsibility reports in accordance with the provisions of the Social Responsibility Guidelines. In the fierce market competition environment, the company pays more attention to the corporate social responsibility report and invests a lot of resources for it. Managers believe that corporate social responsibility activities will create a good social image for the company and thus promote company performance (oladapo, 2013). In the current perspective of global competitive market, companies must endeavor to reveal a picture of themselves as highly socially responsible companies. Active involvement in socially beneficial programs provides extra advantages to the company. Through globalization not a few corporations usually pursue growth and they have faced new challenges that restricted to their growth and potential profits. Companies in different countries of the world have to play a role in social issues otherwise government regulations, environmental restrictions, tariff, varying standards of what constitutes labor exploitation are problems that can cost companies a lot. One of the primary encouraging factors is the idea that Corporate Social Responsibility CSR could be considered to increase long term profitability and sustainability of the company as well as enhance the reputation of the organization.

Over the last three decades, the pressure on firms to engage in CSR has increased. Among the global and/or multinational companies in the world, some view CSR issues as simply a costly hindrance and some companies use CSR methodologies as a strategic tactic to obtain public support for their presence in global markets which could help companies to sustain a competitive advantage by using their social contributions. Researchers around the world have reported a positive, negative, mixed and neutral impacts of corporate social responsibility on corporate financial performance (CFP). On this background, the objective this study is to draw a conceptual framework for examining the direction of linkage between corporate social responsibility and financial performance.

\section{Statement of the Problem}

Corporate Social Responsibility arose as a result of the dynamic changes in which the accounting environment has undergone in the last two decades. The measurement of the relationship between CSR and corporate financial performance (CFP) is perpetually changing, hence the need for an up-to-date study that evaluate this phenomenon. The past two decades have witnessed a remarkable change in the way business is been operated and managed, with the quest for excellence and all-round growth. The pursuit of financial growth does not always lead to social advancement, and is often detrimental to the environment; resulting in unhealthy workplaces, exposure to toxic substances and urban decay and sometimes death of the populace due to inhalation of toxic waste (pollution). Managers and practitioners are often criticized for being single minded about value maximization. The turn of events has pressurized firms to put serious efforts into a wide range of Corporate Social Responsibility (CSR) activities. CSR has become a critical aspect in strategic decision making of a firm primarily due to financial scandals and a drop in investors' confidence. CSR has stepped into the limelight in the 21 st century to add to the financial performance of a company and suggests that corporate decision makers must take care of a range of social and environmental affairs in other to maximize long-term financial returns. Every firm differs in the way it implement CSR in strategic business practices, with its size, operating industry, stakeholder demands, historical CSR engagement, level of diversification, research and development and labour market conditions a few of the factors that determine this decision making. A firm 's cost of adhering to ethical standards will translate into higher product prices, a competitive disadvantage and lower profitability.

Since the popularization of the concept of CSR, there have been different opinions as to what CSR is intended to accomplish for a firm. One of the first influential public figures to air his opinion in the matter was renowned economist and debater Milton Friedman (1970) who claimed that the sole social responsibility of a business is oblige to the wills of its shareholders and increase its profits within the boundaries of laws and business ethics. 
Friedman (1970) further argues that firms should not focus on CSR unless it acts as a value creator and adheres to the wishes of the company's shareholders. Grafström et al. (2008) discusses how the traditional division of stakeholders (customers, citizens, institutions and/or media which are classified as to being directly or indirectly affected by the corporation) is in need of revision, partly due to the digitalization of the world and increased flow and access to information. Due to the debate regarding CSR and its potential value creating capabilities, interest has increased amongst researchers to investigate a potential linkage between CSR and financial performance (Pava \& Krausz, 1996). An early example of such research is McGuire et al. (1988), who examined the relationship between companies CSR activities and financial performance. The researchers concluded that firms low in social responsibility experienced weaker financial performance while noting that low CSR performance also could expose such companies to risks to a larger extent than high performing firms (McGuire et al. 1988). In subsequent years, several researchers have noted similar results regarding a positive relationship between CSR and financial performance (Russo \& Fouts, 1997; Simpson \& Kohers, 2002; Lai et al., 2010; Saeidi et al., 2015). Even so, overall results in the research area are far from univocal as a large number of researchers have failed to identify a positive relationship between the variables (Alexander \& Buchholz, 1978; Stanwick \& Stanwick, 1998; Peng \& Yang, 2014). Some researchers have denoted the inconsistency in results to be caused by differences in selecting methodologies, approaches and selection of variables (Simpson \& Kohers, 2002; Girerd-Potin et al., 2013). Peng and Yang (2014) further argues that most studies in this research area have focused on the US Stock Exchange and that this limits the opportunity to generalize results as the degree of governance, environmental policies and business practices varies globally among different nations of the world. Further, the authors argue that research in the area would benefit from input from other countries to enhance understanding regarding the nature of the CSR and financial performance relationship (Peng \& Yang, 2014).

The Nigerian Securities and Exchange (NSE) Commission issued a directive, mandating large companies to increase its reporting on CSR related matters. This is likely to have a significant effect on Nigerian companies which previously have reported CSR activities on a largely voluntary basis (NSE, 2008). The complexity of the claims made by advocates and assailants of CSR in terms of the value it creates and the costs it incurs raises questions as to what the possible effects of the new NSE regulations will have on businesses operating in Nigeria. Although a large body of research has been devoted to investigating the relationship between CSR and financial performance worldwide, published research devoted to the Nigerian securities and exchange market is scarce. In today's increasingly competitive marketplace and considering the forthcoming regulations for large Nigerian companies to report CSR activities, it should be important to investigate the nature of the relationship between CSR and financial performance in Nigeria companies. If the relationship is determined to be positive, companies could be encouraged to expand its investments and reporting's beyond the required levels. Conversely, if a relationship cannot be observed or is deemed negative, companies might benefit financially from keeping CSR investments and reporting's only at the required level.

The main problem facing Nigeria is to determine if there is significant impact of CSR reporting on the profitability of companies in Nigeria. In view of the above problems, this study assesses the effect of CSR reporting on financial performance of large companies in Nigeria for the past five (5) years with special reference on the performance of manufacturing companies in Nigeria, listed on the Nigerian stock exchange market. This study aims to review alternative operationalisation and measurement approaches for the CSR and CFP constructs deployed in empirical literature concerned with the CSR and CFP relationship. Alternative measurement approaches are identified and analysed. The first contribution of this study is a systematic synthesis of advantages and drawbacks of alternative approaches deployed in existing empirical literature. Two drawbacks identified that are inherent in most approaches are researcher subjectivity and selection bias. The second contribution is a suggestion of potential future pathways for measuring CSR that would remedy these drawbacks. In particular, the study builds a case for standardisation and greater disclosure of CSR information. Such standardisation would not only be beneficial for valid testing of the CSR-CFP relationship but also for a range of stakeholders when making their economic decisions. Thus, the main objective of this study is to assess the effect of CSR reporting on manufacturing companies in Nigeria.

\section{Research Question}

What relationship exist between CSR expenditure on profitability of selected manufacturing firms in Nigeria?

\section{Objective of the Study}

The primary objective of this study is the effect of corporate social responsibility reporting on profitability of selected manufacturing firms in Nigerian stock exchange; to this end, the specific objective is to: determine the relationship that exist between CSR expenditure on profitability of selected manufacturing firms in Nigeria. 
Research Hypothesis

The researcher in a bid to make the above objective achievable, tested the following hypothesis

$\mathrm{H}_{01}$ : CSR expenditure does not have any effect on profitability of selected manufacturing firms in Nigeria.

\section{LITERATURE REVIEW}

\section{Conceptual Review of Literature}

Through corporate social responsibility, businesses reaffirm their principles and values, both in their processes and operations and in their interaction with other social actors. Corporate social responsibility is generally voluntary in nature and refers to activities that exceed a mere compliance with the law. The social and environmental responsibilities of enterprises may reflect the changing expectations of society. For example, what enterprises consider convenient practices today may become indispensable ones tomorrow? In addition, it is expected that different social actors interested in the activities of a certain enterprise will prioritize different social and environmental demands, which may contradict or compete with one another at times.

Corporate social responsibility poses several challenges for enterprises, including the need to define their responsibilities with respect to those of the public sector, determine the extent of their obligations in the supply chain and decide until what point in the future they should anticipate and plan for the consequences of their activities, especially in the case of natural resource use. Pragmatism in corporate social responsibility is essential because despite many issues it can address, corporate social responsibility also has its limits and cannot substitute for the role of government in enforcing laws and international labour standards. Corporate social responsibility as defined by European Commission (2001) is "a concept whereby companies integrate social and environmental concerns in their business operations and in their interaction with their stakeholders on a voluntary basis" following increasingly aware that responsible behaviour leads to sustainable business success. Corporate social responsibility social activities may include charitable contributions to local and national organizations such as fundraising, donations and gifts in areas where it trades and others like regeneration of deprived communities, reclamation of derelict land and creation of new regeneration jobs. However, what cuts across a number of definitions that scholars have proposed on the concept of corporate social responsibility is the general belief that, beyond the quest to maximize corporate profits, corporate organizations play a crucial role in solving society's problems. For Matten and Moon (2004), the fundamental idea of corporate social responsibility is that "it reflects both the social imperatives and the social consequences of business success, and that responsibility accordingly falls upon the corporation, but the precise manifestation and direction of the responsibility lies at the discretion of the corporation." Such a characterization of corporate social responsibility makes it a mandatory exercise in that it assumes that business has a direct responsibility to help in solving society's problems. We argue that, though the modalities of implementing corporate social responsibility programmes are at the discretion of corporate organizations, it does not make corporate social responsibility a freely chosen programme to contribute towards social prosperity.

Therefore, for Aristotle and subsequent proponents of the broader view of corporate social responsibility such as Davis (1983), the widely held narrow view of corporate social responsibility that business is primarily concerned with profit making and maximization than social concern is unrealistic. For Davis, corporate organizations ought to have responsibilities beyond simply enhancing their profits because they enjoy greater social and economic power in any society. The apparent conflict between corporate social responsibility and firm objectives was noticed quite early by the Nobel laureate Milton Friedman, who had declared that any effort to use corporate resources for purely altruistic purposes would constitute socialism. In fact, Friedman recommended that corporation law should be modified to discourage corporate social responsibility (Manne, 2006). And yet more than thirty years after Friedman made his declaration, corporate social responsibility has become the norm. Surprisingly enough, empirical research has indicated positive, neutral and even negative impacts of corporate social responsibility on financial performance. While corporate social responsibility skeptics can explain away the practice of corporate social responsibility as a result of pressure from society, an explanation for the profit motives behind corporate social responsibility becomes even more necessary to explain the source of the social pressure.

Profitability is considered as one of the most important studied indicators of the strategic value of CSR (Ortlitzki, Schmidt, \& Rynes, 2003). Researchers have started the empirical study of CSR and profitability several decades ago in western countries. Many firms have been faced with increasing pressure for corporate accountability from their stakeholders (managers, employees, customer, government, shareholders, and so on) (Waddock, 2004). This pressure includes aspects such as legal, social, moral, and financial aspects. Profitability in this context implies financial performance. However result of existing researches on CSR and its relationship with financial performance, are inconclusive. 
Results of some studies showed a positive relationship between CSR and profitability, on the other hand some concluded that a negative relationship exists while some gave a non-significant relationship.

Ibrahim and Garba (2015) conducted a study on Corporate Social Responsibility and Financial Performance in the Nigerian Construction Industry. The study aimed at assessing corporate social responsibility and financial performance of listed companies in Nigerian construction industry. The study employed both ex-post facto and survey designs, the research generates data from the annual reports and accounts of sampled construction companies and also from questionnaire administered using a five point Likert Scale. Data obtained was analysed using multiple regression analysis and chi-square test. The result of the analysis show that financial performance of the companies in the Nigerian construction industry is impacted more by nonphilanthropic activities than by philanthropic services.

\section{Theoretical Framework}

There are various theories trying to figure out the company responsibilities to the society. They are divided in to two groups, that is, those that suggest a positive relationship between CSR and corporate financial performance and those that depict a negative relationship.

\section{Stakeholder Theory}

This theory emphasizes that the firm has a relationship with its stakeholders and the processes and outcomes of these relationships are of interest (Hillman and Luce, 2001). It purports that since businesses focus to appeal to both financial and non-financial stakeholders, they should focus on engaging in CSR undertakings that are apparently significant to non-financial stakeholder groups. This is because the firm needs both of these groups to be sustainable in the long run. Freeman and Reed (1983) identified two groups of stakeholders; those that affect and can be affected by the firm and those that provide support to the firm in form of resources. Stakeholder theory recognizes the long term effect that the actions of stakeholders may have on the company. Pedersen (2004) notes that maximizing the value of one's stakeholder will maximize the value of the company. Stakeholder relationship will also enhance trade. Kakabadse and Rozuel (2005) emphasizes that, for business to perform well, they must deal with a variety of constituents other than its owners. Jensen (2002) proposes that the society expects the organization to perform various responsibilities in order for them to survive. Zingales (2000) also suggests that firms can only succeed by maintaining a quality relationship with the society.

Freeman (1984) postulated that a firm possesses both formal and informal agreements with numerous stakeholders and are hence liable to honour all such contracts. This enables the company to develop its reputation. Implied contracts become self-regulating through maintaining this relationship and the cost associated with these contracts also reduces (Telser, 1980). Moreover, Tesler argued that it improves performance and reputation of the firm. The function of management is to balance the demand of different existing stakeholders. The stakeholder theory proposes that CSR is positively associated with corporate financial performance. However, there are several critiques from scholars such as Sternberg (1997) who indicates that the theory challenges the property privileges of shareholders. Moreover, Sternberg posits that the theory also undermines the role of capitalism, relegates the role of government and hence compromises the mechanism of the free market.

\section{Slack Resource Theory}

Cyert and March (1963) defined slack resource as any free or underutilized resources that can be redeployed for use by the organization. This theory proposes that companies with slack resources at their disposal have an opportunity to invest more on CSR activities thus improving its corporate social performance (Wissink, 2012). Waddock and Grave (1997) noted that a company is enabled to perform its CSR activities when it has improved financial performance due to the availability of slack resources. The insinuation of this approach is that CSR is an extra cost and social actions by companies can only be pursued if the firm has extra resources or cash flows (McGuire, 1988). Proper utilization of slack resources enhances effectiveness and efficiency and can augment to achievement of organizational goals. Buchholtz (1999) further argued that this enables a firm to effectively adjust to inside burden for modification or to outside burdens for modification in policy.

Whereas CSR may influence the company's financial performance, there is a different direction of causation in this theory where by a CFP-CSP relationship is involved. The financial performance is interpreted as the independent variable and it is the one that drives the corporate social performance which is the dependent variable (Ahmed, 2014). It shows an interesting cycle where by responsibility and improved performance goes hand in hand. There is no clear evidence showing whether slack resources enhances or hinders financial performance (Zhong, 2011). Managers can make decisions that encourage use of its extra resources to engage in useful projects thus positively influence performance. However, agency theory proposed by (Ross, 1973) tends to differ as it 
suggests that slack resources can be a source of agency problem and can cause inefficiencies and thus negatively influence performance.

\section{Agency Theory}

Ross (1973) was among the first scholars to propose the theory. It is defined as the relationship between the owners and the agents. The owners hire the agent to perform work. The owners of the company who are the principals expect the agents to make decisions and act in the principal's interest. The agency theory relies heavily on the notion that the sole responsibility of the corporation is to maximize value of owners. Friedman (1962) uses the agency theory to explain his criticism of CSR by arguing that managers are agents for the owners of the firm. Their only responsibility is to use their assets and take part in activities intended to maximize their returns that results to an increase in the shareholders wealth as long as they act as per the laid down rules and procedures. Gerrans and Murphy (2005), argue that managers should only accept projects that increase shareholders wealth and reject non value adding projects. From the agency theory point of view, CSR is a misuse of corporate resources (Mc Williams and Siengel, 2005) and such resources can be used by firms to engage in other profitable project. Moral hazard and agency cost can also emerge when managers make decisions to invest in CSR activities without any observable consequence.

Jones (2004), posits that the agent is an expert and has an in depth knowledge of that particular industry. He is also aware of the various uncertain outcomes likely to happen more than the principal is. Thus, the principal is required to trust on the agent and should let them work on their behalf. The existing contract between the management and shareholders encourages managers to choose profit maximizing projects. According to Hill and Jones (1992) the principal can prevent deviation from objectives by use of incentives for the agent and incurring monitoring cost. The classical theory supports this theory as it undervalues the possible merits of CSR in terms of resource productivity, cost saving and product differentiation. The agency theory proposes an adverse association concerning CSR and corporate financial performance.

\section{Empirical Review of Literature}

The relationship between CSR and FP has been long studied by scholars but an agreement has never been reached. Various empirical studies have shown different results. Internationally, a study by Fauzi (2009) on organizations listed on the New York Securities Exchange (NYSE) sought to establish the association between corporate financial performance and CSR. The study applied a sample of 101 companies and conducted analysis using a regression model. In the model the independent variable was CSR whereas the dependent variable was financial performance. The study established that CSR did not have any significant effect on corporate financial performance.

Fauzi and Rahman (2007) examined the relationship of CSP and CFP on companies listed in Jakarta stock exchange in Indonesia. Secondary data was collected from audited reports of 383 firms from 2002-2003. Using the Regression model, the study found Link between CSP and CFP to be inconclusive. This study thus did not establish any significant association between CSP and firm performance. Tsoutsoura (2004) conducted a study to establish the association between CSR and FP in California. Data was collected from a sample of 422 firms covering 5 years. Using the regression model, he established a positive and a significant relationship between CSR and financial performance. Gheli (2013) aimed at determining strength direction of the correlation between CSR and company's FP. Data collected from a sample of 322 US companies was covering one year. After a series of regressions, the results indicated existence of a positive significant relationship between CSR and FP.

Ahmed (2014) aimed at explaining the relationship between CSR and CFP. Data was collected from three firms listed in Bursia Malaysia covering from 2007-2011. Using regression analysis, the study concluded existence of a positive relationship between CSR and CFP. Anasthasia and Maria (2010) performed a study on the relation between CSR and FP in the banking sector. The study applied a sample of 189 commercial banks selected from 45 countries. Data available up to 2008 was used. Using regression analysis, the study found no evidence that banks with high CSR activities are more profitable than convention. Thus there is not any positive link between CSR and FP.

Internationally, Okwoma (2012) carried out a research focusing on commercial banks in Kenya on the impact of CSR on FP. The study considered two years where CSR and financial performance measures for 28 banks was studied between the year 2007 and 2008. The study applied ordinary least squares regression model to analyze the data. Findings from the study depicted that CSR had a significant positive effect on corporate financial performance of the surveyed banks. On classification based on size, the study established that there was a 
significant and positive effect of CSR on corporate financial performance of large and medium sized banks. However, the study established that CSR did not have a significant effect on performance of small banks.

A study by Ondieki (2013) in the commercial and services sector of firms listed on the Nigerian stock exchange examined the association between CSR practices and corporate financial performance. Primary and secondary data available as at 31 st December 2012 for the 9 companies listed in the commercial sector was collected. The study used descriptive and inferential analysis to assess the association. Ordinary least squares regression was applied. The study established that there was a positive association between CSR practices and corporate financial performance $(\mathrm{r}=0.987)$. Kipruto $(2014)$ studied commercial banks in Kenya and examined the influence of CSR on financial performance. The study utilized secondary data which was sourced from audited financial statements of the commercial banks, annual reports, websites and publications. Eight out of 44 commercial banks were studied covering over the five year period (2009-2013). Using regression model, the study findings were that expenses on social course have an effect on FP of commercial banks in Kenya. The study also revealed that not all commercial banks report their CSR involvement.

Olaroyeke and Nasieku (2015) conducted an investigation of the effect of corporate social responsibility on the performance of listed manufacturing companies in Nigeria. The population comprised of all the listed manufacturing companies in the Nigerian Stock Exchange. Out of the total 74 quoted companies, 15 companies were randomly selected from five difference sectors of the manufacturing sector. Descriptive techniques were employed in this analysis based on primary data collated from responses of senior managers, chief accountants, and chief auditors. Result revealed that corporate social responsibility activities have a moderate positive effect on the performance of manufacturing companies listed on Nigeria Stock Exchange, and that manufacturing companies engage in CSR not only for profitability but for other reasons such as better corporate image, marketing and advertising strategy; employee satisfaction and fulfillment, improve competitive advantages, productivity and business opportunities; organizational values, among others. The study, therefore, recommended that companies engage in CSR policies and strategies not only to improve their performance but also to strengthening its legitimacy, reputation and building competitive advantage.

Wambui (2012) carried out a research focusing on the partnerships between NGOs and corporate firms assessing the influence of CSR on corporate financial performance. The study focused on a sample of 30 firms and noted that there was a $48 \%$ relationship extent been CSR and corporate financial performance. This implied that companies with the least ROA had an index of $48 \%$ while the maximum of $89 \%$. Mean ROA was about $67.6 \%$ with a standard deviation of approximately $96 \%$. This means that ROA can donate from mean to both sides by 9.6\%. Wambui concluded that CSR and CFP are positively related. Moreover, a study by Obusubiri (2006) assessed the effect of CSR on FP and noted that CSR had a positive association with portfolio performance. Obusubiri attributed these findings to the good corporate image that emanates from companies engaging in CSR activities. Investors are usually attracted to firms that have effective CSR activities making such companies have a good reputation. Mutuku (2004) performed a census survey on 32 companies listed on Nigerian Stock Exchaange. Using regression analysis, he found no relationship between CSR and FP on companies listed on Nigerian Stock Exchange.

\section{METHODOLOGY}

Research design is the structuring of investigation aimed at identifying variables and their relationship to one another. This is used for the purpose of obtaining data to enable the researcher test hypothesis or answer research question. It is an outline or scheme that serves as a guide to the researcher in his effort to generate data for his study. The study was an ex-post facto research design where panel regression was employed by the researcher to understudy the financial statement of the organisations selected for the study. This enabled the researcher to identify the various ways by which expenditure on CSR activities affect the profitability of the organizations selected.

These companies mostly have their corporate headquarters in Lagos Nigeria but have branches in different parts of the country. The study covered five selected manufacturing companies listed on the Nigerian Stock Exchange (NSE). As at $31^{\text {st }}$ December 2018, NSE has about 320 listed securities with a total market capitalization of N24.4 trillion naira. (www.nse.com.ng).

A sample of six (6) companies was selected for the study and the study covered a period of five (5) years from 2013 to 2017. A purposive sampling method was used in the selection of the sample. The six sample selected represent eleven percent $(11 \%)$ of the quoted manufacturing companies in Nigeria. The selected industries represented those that engage in Corporate Social Responsibility, which are either environmentally sensitive in 
their daily operations, or industrial and utility companies which are widely recognized to have the greatest social and environmental problems. These companies also represent those that engage in CSR reporting.

Secondary data was used for the study. The types of data collected are CSR and profit after tax. The secondary data used principally to elicit the required information was the annual report of the selected organizations. The data collected was subjected to statistical analysis using both descriptive and inferential statistics. Simple percentage (\%) and frequency distribution was used to analyse some of the data collected. The descriptive statistics include mean, standard deviations, while inferential statistics that was used in testing the relationship between expenditure on CSR and profitability of the organisations selected for the study include correlation and panel regression. The data was analysed with the help of a statistical package E-VIEWS 10.

\section{RESULTS AND DISCUSSION}

Table 4.1 Correlation Matrix: The study aims to examine the relationship and impact of Corporate Social Responsibilities on the profitability of selected Manufacturing firms in Nigeria. The data for the study was gathered from the financial statement of these companies as quoted on the Nigeria Stock exchange.

\begin{tabular}{|c|c|c|c|c|c|}
\hline Properties & EDU & $\mathrm{HE}$ & NP & $\mathrm{OTH}$ & SI \\
\hline & ‘000 & '000 & ${ }^{\prime} 000$ & '000 & ‘000 \\
\hline Mean & 370970.5 & 411582.2 & 12124776 & 122174.8 & 4477235 \\
\hline Median & 67542.00 & 334806 & 7702395 & 51032 & 4067643 \\
\hline Maximum & 1581086 & 924796 & 64261549 & 555398 & 13956840 \\
\hline Minimum & 3562 & 24734 & 615254 & 1948 & 389147 \\
\hline Std. Dev & 488131.1 & 279465 & 13941142 & 143910.2 & 3496343 \\
\hline skewness & 1.072137 & 0.256274 & 2.105588 & 1.297815 & 0.961529 \\
\hline Kurtosis & 2.710317 & 1.879692 & 7.883859 & 4.016017 & 3.453950 \\
\hline Jarque-Bera & 5.852285 & 1.897242 & 51.98261 & 9711979 & 4.880274 \\
\hline Probability & 0.053603 & 0.387275 & 0.00000 & 0.007782 & 0.087149 \\
\hline Sum & 11129115 & 12347465 & $3.64 \mathrm{E}+08$ & 3665243 & $3.55 \mathrm{E}+14$ \\
\hline observations & 30 & 30 & 30 & 30 & 30 \\
\hline
\end{tabular}

Source: Author's field report

Relationship between Corporate Social Responsibilities and Profitability.

The correlation matrix above shows the degree of relationship that each variable has with one another. The study focusses on the relationship each variable has with the dependent variable Net Profit (NP) and therefore will be explained in this light. It is important to note that the correlation matrix does not give room to consider the heterogeneous characteristics of these variables among the different companies used in these study. Therefore the estimation assumes that all variables originates from a source, nevertheless the result is estimated. The Health expenditure as part of CSR and as an independent variable with the correlation coefficient of 0.378621 shows a weak relationship with the Net profit. This means that the more the companies spend more on health as part of CSR, their profitability do not tend to increase significantly as much as the expenditure on health because there is a weak relationship of about $37 \%$ between the variation of Health expenditure and Net profit.

The Education expenditure as part of CSR displayed a very weak relationship with a correlation coefficient of 0.028718. This means that the variation in Education expenditure as part of CSRs and the variation in the Net profit have just $2.8 \%$ relationship. The coefficient of variation between the Net profit and Social Infrastructure is 0.108228 , i.e the degree of relationship between these two variables is $10.8 \%$. This signifies a very weak relationship between these variables. Lastly, the degree of relationship between Net profit and other expenditure on CSRs by these companies showed a co-efficient of 0.4034 , meaning that other kinds of expenditure which are part of CSRs have about average relation with the Net profit. 
Table 4.2 Descriptive Statistics

\begin{tabular}{|l|l|l|l|l|l|}
\hline & NP & HE & EDU & OTH & SI \\
\hline NP & 1.0000 & & & & \\
\hline HE & 0.378621 & 1.0000 & & & \\
\hline EDU & 0.028718 & 0.098758 & 1.0000 & & \\
\hline OTH & 0.403486 & 0.643433 & 0.037642 & 1.0000 & \\
\hline SI & 0.108228 & 0.650883 & 0.139502 & 0.74475 & 1.0000 \\
\hline
\end{tabular}

Source: Author's field report

From the table above, the mean values of each parameter represents the average value of all the selected companies for the number of years 2013 to 2017. The mean value of Education for all the six companies for five years is 370970.5 , that means on the average 370,970,500 Naira is spent yearly on education as expenditure, also for the gross health expenditure with the mean value of 411582.2 , it means that the average amount spent on health as corporate social responsibility for these 6 companies is 411,582,200 naira in 5 years. The same also applies for other variables (Net profit, Social Infrastructure and Others).

The maximum and minimum represents the maximum and minimum values for each of the series of the variables. The maximum value for NP for all the 6 countries in 5 years between 2013 and 2017 was 64,261,549,000 naira.

Larfarge (according to the data source) while the minimum value was 615254 as Net profit before tax by Vitafoam in 2016. The standard deviation is a measure of dispersion and this explains the degree of deviation from the mean. In the series, the standard deviation of Social infrastructure expenditure (SI) is 3,496,343 i.e the likelihood of deviation from the mean value 4,477,235 is plus or minus 3,496,343 and the deviation of EDU from the mean is 488131.1

\begin{tabular}{|l|l|l|l|l|}
\hline VARIABLES & LLC & IPS & ADF & PP \\
\hline EDU & -0.99179 & 0.40894 & 6.32712 & 8.06788 \\
& $(0.1607)$ & $(0.6587)$ & $(0.8987)$ & $(0.7798)$ \\
\hline HE & 0.88277 & 1.70554 & 4.48637 & 4.24897 \\
& $(0.8113)$ & $(0.9560)$ & $(0.9730)$ & $(0.9787)$ \\
\hline OTH & $-29.6250^{* * *}$ & $-10.1167 * * *$ & $38.8581^{* * *}$ & $38.7444^{* * *}$ \\
& $(0.0000)$ & $(0.0000)$ & $(0.0001)$ & $(0.0001)$ \\
\hline NP & $-5.69458^{* * *}$ & -1.08329 & 14.9864 & $21.2143^{* *}$ \\
& $(0.0000)$ & $(0.1393)$ & $(0.2422)$ & $(0.04703)$ \\
\hline SI & -1.67246 & 0.28231 & 12.6364 & 12.9669 \\
& $(0.0472)^{* *}$ & $(0.3889)$ & $(0.3960)$ & $(0.3714)$ \\
\hline
\end{tabular}

Also involved in the statistical analysis is the skewness and kurtosis of the various variables that are used in the model. The skewness is a measure of the tail shape of the histogram. The decision criterion of the skewness or symmetrical distribution is how close the variable is to zero. A negative skewness indicates that the distribution has a long left tail and a positive skewness indicates that the variable has a long right tail. From the statistical representation in the table above, it can be seen that none of the variables have negative skewness. i.e all the variables have their skewness greater than zero, which means they are all right-tailed with NP having the highest skewness of 2.105588 .

The peak (height) and flatness of the distribution is measured by kurtosis. A normal distribution has 3 as the value of its kurtosis. If it exceeds 3 , then the distribution is highly peaked or leptokurtic, if the kurtosis is less than 3 , the distribution is flat or platykurtic compared with the normal which is referred to as mesokurtic. In the table above, all the variables are leptokurtic asides EDU and HE rate whose kurtosis values are below 3 hence platykurtic. Also, the jarque-Bera is a measurement for the normality of the variables used in the estimation. The jarque-bera is used to checkmate whether the error term is normally distributed or not. It also measures the difference between the skewness and the kurtosis of the series with those from the normal distribution. From table 4.1 we can see that the variables are significant at 5\% level (EDU, NP, OTH) and SI is significant at 10\% except Health (HE) which did not display normal distribution. Therefore we can accept the null hypothesis that the variables are normally distributed. 


\section{Unit Root Test}

The test for unit roots and order of integration of the variables is first conducted on the time series data so as to test for stationarity (or non-stationarity). The existence of unit roots in a series denotes non-stationarity and therefore the regression analysis that will be performed in the traditional way for a non-stationary series will produce spurious results. The goal is to determine if there is stationarity in the data and also the order of integration. Levin-Lin-Chu (LLC), Im. Pesaran Shin test (IPS), Fisher Panel Philips-Peron (PP) are the major Unit root tests that are considered for the stationarity of the data.

The unit root test result is given as follows:

\section{Unit Root at Level}

Note: $* * *, * * *$ denotes rejection of the null hypothesis at $1 \%, 5 \%$ and $10 \%$ respectively. LLC, IPS, ADF, and PP imply Levin, Lin and Chu Test; Im, Pesaran and Shin Test; ADF Fisher Chi-square Test; PP fisher Chi Square respectively. P-values are in brackets.

Table 4.4 First Difference

\begin{tabular}{|l|l|l|l|}
\hline VARIABLES & LLC & ADF & PP \\
\hline HE & $-13.8587 * * *$ & $27.5195 * * *$ & $38.0224 * * *$ \\
& $(0.0000)$ & $(0.0065)$ & 0.0002 \\
\hline EDU & $-2.09530 * * *$ & 12.4805 & 15.9791 \\
& $(0.0181)$ & $(0.4079)$ & $(0.1922)$ \\
\hline SI & & & \\
& $-6.75108 * * *$ & $27.8701 * * *$ & $33.6955^{* * *}$ \\
& $(0.0000)$ & $(0.0058)$ & $(0.0008)$ \\
\hline
\end{tabular}

Source: Author's field report

Note: $* * * * * *$ denotes rejection of the null hypothesis at $1 \%, 5 \%$ and $10 \%$ respectively. LLC, IPS, ADF, and PP imply Levin, Lin and Chu Test; Im, Pesaran and Shin Test; ADF Fisher Chi-square Test; PP fisher Chi Square respectively. P-values are in brackets.

The table above shows the unit root at first difference, the variables HE, EDU, SI have shown to be stationary at $1 \%$ level. The Unit root test at level shows that OTH and NP are stationary at $1 \%$ and $5 \%$ level respectively. But SI and EDU and HE are non-stationary at level and therefore we proceed to take the first difference of the variables that are not stationary.

\section{Estimating the Impact of CSRs on the profitability of the organizations: Panel OLS Estimation}

The study examines the impact of CSR and profitability using the panel OLS analysis. The panel OLS analysis is subdivided into 3 which are:
i. $\quad$ Pooled Panel Analysis
ii. The Fixed Effect Analysis
iii. The Random Effect Analysis

The Panel analysis estimates the impact of Corporate Social Responsibility on the Profitability of the 5 companies (Nestle, Larfarge, Flourmills, Vitafoam, Unilever, Cadbury) by taking the time series data of the whole 6 companies as a whole, without considering whether the companies have heterogeneous characteristics or not. i.e the pooled panel analysis estimates the relationship among these variables as a single data-set neglecting the crosssection and time series nature of the data. Having taken the Logarithms of each variable to minimize scale effect, the result of the pool OLS is given below: 
Table 4.5 Pooled Panel Estimation Result

\begin{tabular}{|l|l|l|l|l|}
\hline Variable & Coefficient & Std. Error & T-stat & Prob. \\
\hline $\mathrm{C}$ & 9.924963 & 2.149795 & 4.616702 & 0.0001 \\
\hline $\operatorname{lnEDU}$ & 0.180795 & 0.087107 & 2.075558 & 0.0484 \\
\hline $\ln \mathrm{HE}$ & 0.430502 & 0.281472 & 1.529465 & 0.13817 \\
\hline $\ln \mathrm{OTH}$ & 0.489710 & 0.136337 & 3.591916 & 0.0014 \\
\hline $\operatorname{lnSI}$ & -0.467960 & 0.233541 & -2.003757 & 0.0560 \\
\hline R-squared & 0.753925 & & & \\
\hline Adjusted R- Squared & 0.714553 & & & \\
\hline F-stat & 19.14897 & & & 0.00000 \\
\hline Durbun-Waston & 1.308625 & & & \\
\hline
\end{tabular}

Source: Author's field report

\section{The Fixed Effect Analysis}

The fixed effect analysis allows for heterogeneity or individuality among the 6 companies by allowing the 6 companies to have separate intercepts because of other variables that are not in the model but are correlated with the explanatory variables which will in turn affect the outcome of the dependent variable. The term "fixed" is due to the fact that although the intercepts across the countries may differ, but they remain time invariant i.e they do not vary over time. The easiest way to estimate the the fixed effect model is to include a set of dummy variables one for each company and include them as regressors. The fixed effect result is presented below:

Table 4.6 Fixed Effect Model

\begin{tabular}{|l|l|l|l|l|}
\hline Variable & Coefficient & Std. Error & T-Stat & Prob \\
\hline C & 25.34769 & 4.591278 & 5.520836 & 0.0000 \\
\hline $\operatorname{lnEDU}$ & 0.785366 & 0.192681 & 4.077370 & 0.0005 \\
\hline $\ln \mathrm{HE}$ & -0.477730 & 0.458319 & -1.042959 & 0.3091 \\
\hline $\ln \mathrm{OTH}$ & 0.048470 & 0.257637 & 0.188132 & 0.8526 \\
\hline $\ln \mathrm{SI}$ & -1.035118 & 0.371150 & -2.788947 & 0.0110 \\
\hline R-squared & 0.849994 & & & \\
\hline Adjusted R-squared & 0.792849 & & & \\
\hline F-stat & 14.87429 & & & 0.0000 \\
\hline Durbun-Waston & 1.663926 & & & \\
\hline
\end{tabular}

\section{Source: Author's field report}

\section{Random Effect Model}

In random effect, the individual-specific differences across the companies is assumed to be a random variable that does not correlate with the independents variables, i.e these differences has little or no relationship with the explanatory variables. The fundamental difference between the fixed and random effect is whether the variables that were not captured in the model posess characteristics that are correlated with other explanatory variables or not. The result is presented below:

Table 4.7 Random Effect Estimation

\begin{tabular}{|l|l|l|l|l|}
\hline & & & & \\
\hline Variable & Coefficient & Std. Error & T-stat & Prob. \\
\hline $\mathrm{C}$ & 9.924963 & 1.552894 & 6.391267 & 0.0000 \\
\hline $\operatorname{lnEDU}$ & 0.180795 & 0.062921 & 2.117360 & 0.0082 \\
\hline $\ln \mathrm{HE}$ & 0.430502 & 0.203320 & 2.117360 & 0.0444 \\
\hline $\ln \mathrm{OTH}$ & 0.489710 & 0.098482 & 4.972574 & 0.0000 \\
\hline $\operatorname{lnSI}$ & -0.467960 & 0.168698 & -2.773960 & 0.0103 \\
\hline R-squared & 0.753925 & & & \\
\hline Adjusted R-squared & 0.714553 & & & \\
\hline F-stat & 19.14897 & & F. Prob. & 0.0000 \\
\hline Durbun-Waston & 1.308625 & & & \\
\hline Source: & & & \\
\hline
\end{tabular}

Source: Author's field report 
In selecting the most appropriate model among the three models, The Hausman test and Wald test is applied. The correlated random effects-Hausman test is used to select the right model between the fixed and random effect, if the fixed model is suitable, then we proceed further to select the suitable model between the fixed effect model and the pooled panel OLS result using the Wald test. The correlated random effect Hausman test is presented below:

\section{Table 4.8 Hausman Test}

\begin{tabular}{|l|l|l|l|}
\hline Test Summary & Chi-Sq statistic & Chi-sq d.f & Prob \\
\hline Cross-section random & 27.854073 & 4 & 0.0000 \\
\hline
\end{tabular}

Source: Author's field report

The probability value here is lower than $5 \%$, thereby we reject the null hypothesis and conclude that the fixed effect model is more appropriate. . In selecting between the fixed effect and the pooled OLS results the Wald test is applied. The Wald test tells us whether all the Coefficients dummy variables are significant in selecting the right model or not. The null hypothesis is that the pooled regression is the right choice, while the alternative hypothesis states that fixed effect model is appropriate. The result of the Wald Test is presented below:

Table 4.9 Wald Test

\begin{tabular}{|l|l|l|l|}
\hline Test Statistic & Value & D.f & Prob \\
\hline F-Stat & 3.362264 & 4,21 & 0.0282 \\
\hline Chi-Square & 13.44906 & 4 & 0.0093 \\
\hline
\end{tabular}

Source: Author's field report

From this result, the F-statistic value is 3.362264 with the probability value of 0.0282 which is evidently less than $5 \%$. Therefore, we can reject the null hypothesis and accept that the fixed effect model the appropriate model. In other words, this explains to us that there are heterogenic characteristics in the profitability and performance of each firm, these heterogenic qualities are not captured by the explanatory variables (EDU, HE,SI, OTH) that are used in the course of estimation. These heterogenic characteristics do not vary with respect to time but are correlated with the explanatory or independent variables. These characteristics may include differences in geographical location and part of the population that benefit more from these CSRs, the different administrative structure and policies of these firms as touching CSRs, the type of industry which the firm is operating in e.t.c. Another important characteristic to take note of as a result of selecting this model is that the time-invariant characteristics of these companies are not correlated with other individual entity's (other companies) characteristics, fixed effect remove the effect of those individual characteristics so that we can assess the net effect of the independent variables that were used in this study.

\section{Fixed Effect Result Interpretation on the impact of CSR on Firm's profitability}

Having carried out appropriate tests the fixed effect model shows to be the appropriate model to measure the impact of CSRs on the profitability of these companies. From the result of the fixed effect model, the R-squared co-efficient is given as 0.849994 . The R-sqared explains the percentage variation in the dependent variable that is explained by the independent variables. In other words, $84 \%$ of the variation in the Net Profit is explained by the explanatory or independent variables $(\operatorname{lnEDU}, \operatorname{lnHe}, \operatorname{lnSI}, \operatorname{lnOTH})$. This means that a very good percentage of the movement or changes in the Net Profit of each company is determined by how much each company spends on corporate social Responsibilities. This is also confirmed from the F-statistics, the F-statistic with a value greater than 1.96 shows the overall significance of the independent variables in determining the value or movement of the dependent variable. From the result presented above the F-stat assumed a value of 14.87429 clearly signifying the overall significance of the variables. The result also does not suffer from auto-correlation with the value of Durbinwaston being 1.664. Auto-correlation is a situation where the explanatory variables or independent variables that are used in the estimation determines the values of one another i.e a situation where $\operatorname{lnEDU}, \ln \mathrm{hE}, \ln \mathrm{SI}$ and $\operatorname{lnOTH}$ have strong relationship such that the values of one can be predicted from the other, it is often referred to as an estimation problem. Two of the variables Education (lnEDU) and Social infrastructure (lnSI) have shown to be significant at $1 \%$ level and two other variables have shown to be insignificant in determining the net profit.

The coefficient of lnEDU shows a positive relationship with the Net Profit at 0.785366 . In explaining this, $1 \%$ increase in education expenditure will induce $0.7854 \%$ increase in the net Profit. In other words, the education expenditure and the Net profit have positive relationship, in the same vein a $1 \%$ reduction in education expenditure will reduce net profit by $0.7854 \%$. This result showed that the marginal effect of this variable on net profit is significant at $1 \%$ error margin by the t-statistic having displayed a value of 4.077 which is evidently greater than 
1.96. In this wise, the education expenditure as part of CSRs of the selected companies have shown to be very important in determining whether there is an increase or a reduction in the profitability of these companies. This is explainable and understandable as expected because education plays a very significant role in the society and in the people who benefit from these corporate social responsibilities (CSRs) will in the long-run have a way of benefiting the organization whether directly or indirectly. Whether through being employed by the organization back as inputs or through earning income through which the individuals can patronize these companies and increase their revenue thereby increasing profitability. Therefore this implies that more funds should be directed towards the education sector because of its influence on the availability of human capital needed for the better performance of domestic firms.

Furthermore the health expenditure as a part of CSR showed a negative relationship with the profitability of the selected companies by having a coefficient of -0.47773 . The health expenditure by these companies refers to the total amount each company dispenses per year as part of Corporate Social Responsibility. The coefficient of 0.47773 implies that $1 \%$ change in health expenditure (as part of CSR) should reduce the profitability of the companies by $0.47773 \%$ and a reduction in Health Expenditure tends to increase the profitability of the companies. This might be as a result of the companies not giving enough funds to their expenditure on human capital, or a situation where the funds that are meant to be dispensed as part of CSR do not pass through the right channel and therefore either mismanaged or embezzled by some set of people, or the funds is not getting to the desired destination and achieving the purpose for which it was meant. But the result is doubtable because of the insignificance of the variable by having a P-value more than $0.05 \%$.

The expenditure on social infrastructure (SI) can also be deduced to have a negative relationship with NP. The coefficient of Social infrastructure expenditure is -1.035118 . This serves as the highest marginal effect among the variables used for this study. The negative relationship between Social Infrastructural expenditure and the Profitability of these companies implies that the both of them move in an opposite direction, this is similar to the nature of relationship the Health Expenditure has with Profitability. A negative relationship implies that the two variables move un the opposite direction i.e 1\% increase in the amount dispensed as Social Infrastructural Expenditure (as being part of CSR)will induce $1.035 \%$ reduction in the profitability of the companies. From the estimation of the result, this variable is significant at $1 \%$ with a probability value of 0.011 implying the high significance of the result. The opposite movement of these 2 variables implies that increase in SI does not positively influence the Net profit. This can also be due to the fact that the funds meant for the provision of social infrastructure by these firms have not been channeled through the right source or have probably been inflated as quoted by these companies. Social infrastructures include the construction of roads, provision of electricity in the area where these firms are located therefore the provision or availability of these infrastructures should ordinarily increase their profitability but this has demonstrated a negative and significant relationship. This could be caused by embarking on projects without completing them due to lack of funds for its completion, or a situation where the effect of the projects carried out by the firms do not yield up to the desired and expected results. It could also be due to low technical know-how of the officials in charge of these social infrastructural projects or a situation where sub-standard infrastructural facilities are provided and instead of inducing profitability, it reduces it.

Other CSRs denotes other expenditures which are part of the expenditure on corporate social responsibilities (CSRs) but are not classified under Health, Education and social infrastructure. The coefficient of OTH at 0.04847 implies a positive relationship with the NP. That is, $1 \%$ increase in this expenditure will induce 0.04847 positive change in the profitability of these companies. The result is not significant because the P.value is greater than 0.05 , therefore this relationship cannot be totally reliable.

Therefore, we can reject the null hypothesis that Corporate Social expenditure does not influence or impacts the financial performance of manufacturing firms in Nigeria and accept the alternative hypothesis that CSR is significant is determining the financial performance and profitability of selected manufacturing firms in Nigeria. In this light, more funds should be provided by these firms to improve the human capital composition of the society and provide infrastructural facilities in an enabling environment which in the long-run benefit the firms and populace.

\section{CONCLUSION AND RECOMMENDATIONS}

The findings from the study showed that CSR expenditure significantly influenced profitability of manufacturing companies quoted on the Nigerian stock exchange. From the findings, the researcher therefore conclude that companies that place more emphasis on CSR, measuring it and treating it an obligation will stand apart. Also, companies that do a proper job of making sure that the society to which they belong, feels their impact are going 
to be in a position to have a sustainable competitive advantage. In today's global business environment and a changing world, success is driven by a lot of factors among which CSR expenditure is also inclusive. Companies should therefore ensure they act as good citizen of the society to which they belong for the ongoing success of the business.

The study offer the following policy suggestions on how firms can improve on their CSR to ensure greater and better performance; Policy framework should be design for corporate social responsibilities in Nigeria by the Government and ensure compliance by setting mechanisms and institutions for the implementation of CSR. Companies in Nigeria particularly the profitable one should give greater priority to CSR. This has the tendency to assist them to survive and maintain their profitability. Attention should be given to social accounting and social costs by firms in Nigeria.

The study recommended that manufacturing companies should increase their dedication to giving back to the society, by formulating a framework for CSR spending to boost the standard of live of Nigerians to the point that their social reputation will engender positive and substantial increase in their profitability, as this is essential for their going concern in the country.

This also recommends a mandatory CSR reporting framework in line with international best practice for all listed companies in Nigeria. Current trends of integrated reporting worldwide calls for Nigerian companies to consolidate social, environmental and financial information, disclosing the positive with the negative in order to provide greater transparency and helping to build superior trust.

\section{REFERENCES}

Adebayo, O., Oluwatoyosi, O.T. \& Elizabeth, O.M. (2012), “Corporate Social Responsibility Reporting and Financial Performance of Money Deposit banks in Nigeria Prime Journal of Business Administration and Management (BAM) ISSN: 2251-1261. Vol. 2(11), Pp. 758- 769, November 13th, 2012. www.primejournal.org/ BAM (C) Prime Journals

Adeboye, O.R., \&Olawale, S.R. (2012). Corporate Social Responsibility (CSR) and Business Ethics (Be): Effective Tools For Business Performance in Nigerian Banks. IjcrbWebs.Com Interdisciplinary Journal of Contemporary Research in Business Copy Right (C) 2012 Institute of Interdisciplinary Business Research 274 September 2012. Vol. 4, No 5

Ajao, O.S. \& Obida, S.S. (2012). Liquidity management and corporate profitability; Case study of selected manufacturing companies in Nigerian Stock Exchange. Business Management Dynamics, 2 (2), 10-25.

Alexander, G. \& Buchholz, R.A. (1982). Corporate social responsibility and stock Market Performance. Academy of Management Journal, 21(3), 479-486.

Allen, L. (2014). Corporate social responsibility and financial performance in the consumer and non consumer sector. Thesis at Claremont Mckennacollege.

Amaeshi, K., Adi, B. Ogbechie, C. \& Amao, O. (2006). "Corporate Social Responsibility in Nigeria: Western Mimicry or Indigenous Influences?” No. 39- 2006, ICCSR Research Paper Series - ISSN 1479-5124, The University of Nottingham, pp. 1- 44.

Babalola, Y. A. (2012). The Impact of Corporate Social Responsibility on Firms' Profitability in Nigeria. European Journal of Economics, Finance and Administrative Sciences, 45, 39-50.

Bahman, S.P., Kamran, N. \& Mostafa, E. (2014). Corporate Social Responsibility: A Literature review. Academic Journal, 8(7), 228-234.

Bhagat, S. \& Bolton, B. (2009). Corporate Governance and Financial performance: Recent evidence. PHD Thesis University of Colorado.

Bolanle, A.B. Olanrewaju, A. S. \& Muyideen, A. A. (2012):"corporate social responsibility and profitability of Nigeria Banks- causal Relationship" Research Journal of Finance and Accounting ISSN 2222-1697 Vol. 3, No 1 www.iiste.org

Carroll, A. B. (1979). Business and society: Ethics and stakeholder management. Cincinnati, OH: South-Western.

Carroll, A. B. (1991). The pyramid of corporate social responsibility: Towards the moral management of organisational stakeholders. Business Horizons, 34, 39-48.

Corporate social responsibility - What does it mean? Retrieved December 27, 2003, from http://www.mallenbaker.net/csr/CSRfiles/ definition.html

Cyert, R. \& March, J. G. (1963). A Behavioral Theory of the Firm. Englewood Cliffs, NJ: Prentice-Hall.

Daniel, O .O. (2010). Effect of corporate social responsibility on financial Performance of commercial banks in Kenya. Unpublished MBA Project University of Nairobi.

Davis, K., \& Blomstrom, R. L. (1966). Business and its environment. New York, NY: McGraw Hill. 
Enahoro, J. A., Akinyomi, O. J., \& Olutoye, A. 1. (2013). Corporate Social Responsibility and Financial Performance: Evidence from Nigerian Manufacturing Sector. Asian Journal of Management Research, 4(1), 153-162.

Flammer ,C. (2013). Does corporate social responsibility lead to superior performance? A regression discontinuity approach. Cambridge, USA: MIT Sloan School of Management.

Foote, J., Gaffney, N. and Evans, J. R. (2014). CorporateSocial Responsibility: Implication for Performance Excellence. Total Quality Management. 21(8), 799-812.

Foote, J., Gaggfney, N. \& Evans, J.R. (2010). Corporate Social Responsibility: Implications for performance excellence. Total Quality Management, 21(8), 799-812.

Frederick, W. C. (2016). 'The growing concern over business responsibility. California Management Review, 2, 54-61. doi:10.2307/41165405

Freeman, E. (1984). Strategic management: A stake holder approach Boston M.A; Pitman.

Friedman, M. (1970). The social responsibility of business is to increase profit. New York Magazine. Bellingham, Washington.

Friedman.M. (1962). Capitalism and freedom a leading economist view of the proper role of Competitive capitalism. Chicago. The university of Chicago press.

Gibson, K. (2000). The moral basis of stakeholder theory. Journal of Business Ethics. 26, pp 245-257.

Greyer, E. H., \& Ross, W. T..(1997). The influence of firm behaviour on purchase intention: Do consumers really care about business ethics? Journal of Consumer Marketing, 14(6], 421-432. Academy of Management Review, 4(4), 497-505,

Hossein, K. H. \& N. K. \& E. M. \& A. S. (2012). Impact of Corporate Social Responsibility Activities on Company Performance Interdisciplinary Journal of Contemporary Research in Business. Interdisciplinary Journal of Contemporary Research in Business, Vol 3(No 9), pp 583 -592.

Iqbal, N., Ahmad, N., Basheer, N. A., \& Nadeem, M. (2012). Impact of Corporate Social Responsibility on Financial Performance of Corporations: Evidence from Pakistan. International Journal of Learning \& Development, 2(6), 107-118.

Jones, T. M. (1980). Corporate social responsibility revisited, redefined. California Management Review, 22(3), 59-67. doi:10.2307/41164877.

Korkchi, S., \& Rombaut, A. (2006). Corporate Social Responsibility. A case of private and public corporations. $1(3), 56-71$.

McWilliams, A., \& Siegel, D. (2000). Social responsibility and Financial Performance: Correlation or Misspecification? Strategic Management Journal, 21, 603-609.

Mujahid, Mubeen and Abdullah, Arooj. (2014). Impact of Corporate Social Responsibility on Firms Financial Performance and Shareholders Wealth. European Journal of Business and Management. 6(31), 181-187.

Obi, D. (2013). CSR: 8 banks spend N1.9bn to make social impact, This Business day News paper of July 9th, available at : www.businessdayonline.com. Accessed on October,18th, 2013.

Ofori, D.F., Nyuur, R. B. \& S-Darko, M. D. (2014). Corporate social responsibility and financial performance fact or fiction look at Ghanian banks. Acta commercial arts 14 (1), 180-1045.

Ogore, V.O. \& Kusa, G.B. (2013). Determinants of financial performance on commercial banks in Kenya. International Journal of Economics and Financial review, 3(1), 237-252.

Ohiokha, F.I, Odion O.A, and Akhalumeh, P.B (2016) corporate social responsibility and corporate financial performance: the Nigerian Experience. International journal of accounting research. 2(10), 34-43.

Omondi, M. (2013). Factors affecting financial performance of companies listed at the NSE.. Research Journal of Finance and Accounting, 4 (15), 99-103.

Omwega, D. K. (2014). The relationship between corporate social responsibility and financial performance of companies listed in the NSE, Unpublished MBA project University of Nairobi.

Ondieki, D.O. (2013). Relationship between CSR practices and financial performance of the firms listed in the commercial and service sector at the Nairobi Securities Exchange. Unpublished MBA project University of Nairobi.

Pava, M .L. \& Krausz, J. (1996). The association between corporate social responsibility and Financial performance. Paradox of social cost. Journal of Business Ethics 15 (3), 321-357.

Pedersen, T. (2004). Stakeholder theory, Lesson from Denmark. A thesis department of finance Aarhus School of Business.

Pervan, M. \& Vinsic, J. (2012). Influence of firm size on its business success. Croation Operational Research Review, 3 (1), 210-230. 


\section{APPENDICES}

\section{NESTLE}

\begin{tabular}{|l|l|l|l|l|l|}
\hline Year & $\begin{array}{l}\text { Net Profit } \\
\text { Before Tax }\end{array}$ & $\begin{array}{l}\text { Social } \\
\text { Infrastructure }\end{array}$ & Education & Health & Others \\
\hline & N'000 & N'000 & N'000 & N'000 & N'000 \\
\hline 2017 & $24,445,978$ & $9,196,332$ & 939,147 & 909,535 & 311,998 \\
\hline 2016 & $26,047,590$ & $8,001,617$ & 941,593 & 799,357 & 298,499 \\
\hline 2015 & $25,050,172$ & $7,081,299$ & 791,461 & 680,356 & 278,130 \\
\hline 2014 & $18,199,249$ & $6,069,387$ & 665,503 & 621,354 & 227,184 \\
\hline 2013 & $18,244,454$ & $4,901,143$ & 545,790 & 712,660 & 123,890 \\
\hline
\end{tabular}

LARFARGE

\begin{tabular}{|l|l|l|l|l|l|}
\hline Year & $\begin{array}{l}\text { Net Profit } \\
\text { Before Tax }\end{array}$ & $\begin{array}{l}\text { Social } \\
\text { Infrastructure }\end{array}$ & Education & Health & Others \\
\hline & N'000 & N'000 & N'000 & N'000 & N'000 \\
\hline 2017 & $41,198,427$ & $1,124,673$ & 45,978 & 345,770 & 166,580 \\
\hline 2016 & $64,261,549$ & 635,614 & 35,493 & 467,134 & 123,657 \\
\hline 2015 & $5,473,736$ & $2,119,152$ & 10,776 & 170,775 & 145,700 \\
\hline 2014 & $4,114,287$ & $3,999,449$ & 68,301 & 924,796 & 135,372 \\
\hline 2013 & $8,464,365$ & $2,516,367$ & 55,211 & 833,513 & 164,598 \\
\hline
\end{tabular}

FLOURMILLS

\begin{tabular}{|l|l|l|l|l|l|}
\hline Year & $\begin{array}{l}\text { Net Profit } \\
\text { Before Tax }\end{array}$ & $\begin{array}{l}\text { Social } \\
\text { Infrastructure }\end{array}$ & Education & Health & Others \\
\hline & N'000 & N'000 & N'000 & N'000 & N'000 \\
\hline 2017 & $8,227,983$ & $12,203,537$ & 231,359 & 677,405 & 555,398 \\
\hline 2016 & $10,876,848$ & $13,956,840$ & 190,586 & 598,634 & 354,772 \\
\hline 2015 & $11,803,161$ & $8,756,978$ & 87,560 & 566,977 & 56,432 \\
\hline 2014 & $16,445,415$ & $7,906,434$ & & 585,963 & 123,899 \\
\hline 2013 & $24,439,549$ & $6,717,606$ & 56,783 & 431,396 & 387,690 \\
\hline
\end{tabular}

\section{CADBURY}

\begin{tabular}{|l|l|l|l|l|l|}
\hline Year & $\begin{array}{l}\text { Net Profit } \\
\text { Before Tax }\end{array}$ & $\begin{array}{l}\text { Social } \\
\text { Infrastructure }\end{array}$ & Education & Health & Others \\
\hline & N'000 & N'000 & N'000 & N'000 & N'000 \\
\hline 2017 & $1,467,314$ & $4,135,837$ & 88,355 & 583,327 & 13,564 \\
\hline 2016 & $7,421,477$ & $4,322,662$ & 32,230 & 300,827 & 15,773 \\
\hline 2015 & $4,123,959$ & $4,315,743$ & 31,342 & 285,179 & 12,328 \\
\hline 2014 & $5,082,637$ & $4,379,448$ & 34,627 & 247,717 & 22,930 \\
\hline 2013 & $1,952,559$ & $3,496,912$ & 45,230 & 297,514 & 10,944 \\
\hline
\end{tabular}

\section{UNILEVER}

\begin{tabular}{|l|l|l|l|l|l|}
\hline Year & $\begin{array}{l}\text { Net Profit } \\
\text { Before Tax }\end{array}$ & $\begin{array}{l}\text { Social } \\
\text { Infrastructure }\end{array}$ & Education & Health & Others \\
\hline & N'000 & N'000 & N'000 & N'000 & N'000 \\
\hline 2017 & $2,873,235$ & $4,362,430$ & $1,581,086$ & 323,843 & 45,632 \\
\hline 2016 & $6,793,615$ & $3,507,818$ & $1,126,661$ & 264,515 & 21,579 \\
\hline 2015 & $8,815,987$ & $3,082,108$ & $1,019,084$ & 210,821 & 12,864 \\
\hline 2014 & $7,983,312$ & $2,698,008$ & $1,052,237$ & 162,515 & 13,760 \\
\hline 2013 & $6,151,855$ & $2,040,184$ & $1,363,140$ & 151,727 & 23,887 \\
\hline
\end{tabular}




\section{VITAFOAM}

\begin{tabular}{|l|l|l|l|l|l|}
\hline Year & $\begin{array}{l}\text { Net Profit } \\
\text { Before Tax }\end{array}$ & $\begin{array}{l}\text { Social } \\
\text { Infrastructure }\end{array}$ & Education & Health & Others \\
\hline & N'000 & N'000 & N'000 & N'000 & N'000 \\
\hline 2017 & 709,772 & 775,855 & 7,197 & 52,545 & 2,619 \\
\hline 2016 & 615,254 & 605,587 & 3,562 & 48,289 & 4,632 \\
\hline 2015 & 812,729 & 561,890 & & 37,829 & 1,948 \\
\hline 2014 & 823,566 & 456,987 & 3,781 & 30,458 & 4,958 \\
\hline 2013 & 823,252 & 389,147 & 4,659 & 24,734 & 4,026 \\
\hline
\end{tabular}

